\title{
Job autonomy and Job Satisfaction of English Instructors in the language Centers of some Private Colleges in Muscat, Oman
}

Najah Salim Al-Siyabi*

EFL Teacher, Muscat College, Muscat, Sultanate of Oman

\begin{abstract}
The purpose of this study to examine the relationship between teachers' job autonomy and Job satisfaction. The research also investigated the most critical facets of job satisfaction. Variables in this research were measured via two surveys consisting of 70 English faculty members in the language centers of 6 private colleges in Muscat. Results showed that job autonomy is significantly related to job satisfaction. It also showed that the respondents displayed high level of job satisfaction and job autonomy. In addition, this research found that payment was the less satisfactory aspect among the lecturers. There was no significant relation between the instructors' experience, gender and their job satisfaction and job autonomy. Finally, this study has educational implications for the managers to set a satisfied environment of working for the instructors.
\end{abstract}

\section{Publication History:}

Received: December 16, 2015

Accepted: March 14, 2016

Published: March 16, 2016

\section{Keywords:}

Job satisfaction, Job autonomy, Instructors

\section{Introduction}

Teachers are the key stone of the learning process in all educational fields. They are the strength of a nation since they are the ones who lead the system of education into success or failure. Through the last decades, it has been considered that teaching is one of the most stressful and demanding profession. The task of producing qualitative educational output has been an essential subject of concern. Therefore, developing teachers' career besides satisfying their professions' needs has been a crucial task among educational researchers, policy makers, practitioners and administrators. In particular, job satisfaction leads to full devotion and commitment. It also expresses the extent of matching between the employee's expectations from the job and the rewards that the job provides [1]. Accordingly, lots of research efforts have been directed towards teachers' job satisfaction.

Taylor, et al. [2] states that job satisfaction among college teachers' increases productivity and classroom performance and when they are satisfied; their teaching will be effective and efficient. In addition, satisfied teachers can contribute highly to the well-being of their students. In contrast, unsatisfied teachers might have tension that affects negatively on the students' academic growth [3].

Ali, et al. [3] explains that job satisfaction refers to 'a pleasurable emotional state resulting from the appraisal of one's job". Wikhes has defined job satisfaction as the extent to which one feels good about the job he/she does. Based on these definitions, the researcher particularly defines teachers' job satisfactions as teachers' gratification with teaching.

Other predictors of teachers' job satisfaction have been proposed by Ghenghesh [7]; they are Characteristics of the teacher workload, working conditions, curriculum, and teacher autonomy. Perveen and Ghughati [4] identify motivation as a key determinant of teacher satisfaction. They emphasized that motivation is considered to be the driving force behind all actions performed by the teachers. Peter [8] also recommends that teachers' freedom in designing their lessons and flexibility in the areas of personal professionals is one of the most vital job satisfaction determinants. The teachers should get the opportunity to construct the subject's content and methods they use. They should be provided with better training methods and all are allowed to be a part in decision making. Agyekum [9] also suggests some variables that may have significant relation to teachers' job satisfaction. He argues that teachers have more satisfaction in communities which provide adequate social resources. These resources include education and health facilities, markets and electricity.

\section{The Relationship between Perceived Autonomy and Intrinsic Motivation}

Previous studies have suggested that there is a significant role for intrinsic motivation in producing outcomes. Gagné, et al. [10] states that intrinsic motivation involves people doing activities that are interesting. According to SDT, autonomy is the strongest predictor of intrinsic motivation. Liang \& Qingguo examined this relation and proposed that managers shouldn't focus on monetary rewards only as they will result in reducing the intrinsic motivation as well as the employees' autonomy. The authors also suggested that autonomy can influence intrinsic motivation through manipulating the opportunity for employees to choose tasks. Many studies guided by SDT have provided support to this perspective. For example, Hackman \& Oldham [11] argued that the most effective means of motivating employees is through the design of jobs. This can be achieved through affording considerable freedom for the employee, providing variety and timely constructive feedback.

\section{Teachers' job autonomy}

Job autonomy is a critical and contemporary term associated with educational quality, innovation of the schools, colleges and universities for many positive work outcomes. Langfred and Moye [12] argue that teachers' autonomy is, relatively a modern phenomenon. Many researchers have found positive association between job satisfaction and job autonomy. According to Saragih [13], teachers with job autonomy will be more motivated to do their best and lead to higher performance. Skinner [14], in examining the work of Miron, stated that academic productivity is due to teachers' feeling of ownership

"Corresponding Author: Najah Salim Al-Siyabi, EFL Teacher, Muscat College, Muscat, Sultanate of Oman, Tel: +968 92828092, E-mail: najah@muscatcollege.edu.om

Citation: Al-Siyabi NS (2016) Assistive Technology for Promoting Adaptive Behaviors of Children with Cerebral Palsy. Int J Psychol Behav Anal 2: 111. doi: http://dx.doi.org/10.15344/2455-3867/2016/111

Copyright: (C) 2016 Al-Siyabi et al. This is an open-access article distributed under the terms of the Creative Commons Attribution License, which permits unrestricted use, distribution, and reproduction in any medium, provided the original author and source are credited. 
and autonomy. Generally, autonomous teachers would demonstrate less job stress and greater work satisfaction. The degree of autonomy perceived by teachers is an indication of current job satisfaction [15].

Donge [16], in examining Van Veen, claims that the concept of autonomy in old Greek is "autonomia" which derived from "autos" that means self and "nomos" which means habit or rule. The pioneers of the concept job autonomy are Turner and Lawrence who built up teachers' characteristic among which was job autonomy. Wikhes defines teachers' job autonomy as teachers' "involvement in a variety of activities related to their diverse roles, curriculum designers, administrators and assessors". Other scholars define the concept in a more comprehensive way. For example, Wikhes claims that teacher autonomy doesn't refer to teacher isolation, but should be perceived in terms of freedom for professional action. Based on the previous definitions, teachers' job autonomy can be defined as the degree to which the teaching provides teachers with freedom and independence in scheduling their work. Dobbin and Boychuk [17] maintain that job autonomy consists of external opportunities like contextual autonomy, control over outcome, control over work and internal components like content autonomy, operation autonomy, and control over activity.

Job autonomy conceptualization can be related to some theories. Maslow, for example, talks about autonomy in his hierarchy ranging from psychological sustainability to self- actualization. McClellandalso takes the concept job autonomy in terms of formulating the requirements for achievement, affiliation and power [18]. Most prominent is self-determination theory. It postulates three innate psychological needs that are, need for competence, need for relatedness and need for autonomy.SDT mainly proposes that individuals are intrinsically motivated to engage in self- determined actions; actions that allow us to be autonomous [19].

Paying attention to the role of autonomy as a crucial predictor of job satisfaction is a worthwhile effort. To start with, job autonomy allows the teachers to limit the work stress and reduce the feeling of threat [11]. People with high job autonomy are psychologically well- adjusted. They are also at low risk of psychological therapy. Job autonomy also creates balance between dependency and independency [20]. Autonomy helps in maintaining intrinsic motivation. For example, autonomy helps teachers contribute to their students' greater intrinsic motivation, curiosity and the desire for challenge [21]. Also, autonomy reflects strong self-awareness and selfinsight [22]. Donge [16] also found that job autonomy supports the employee's well- being and health. Ngyen et al. [2] also pointed out that educators should care about job satisfaction since it works as a predictor of a worker's behavior. Samman [23] asserts that autonomy is an indicator of psychological well-being.

In the light of the above theoretical framework and previous studies, the purpose of this study was simply to determine how job autonomy is related to job satisfaction. It has been claimed that if the teachers are contented with their jobs, they will maintain high level of performance, thus, the learning process would be more efficient. This study, in fact, was guided by the following questions:

- What are the levels of job satisfaction and job autonomy of the College teachers?

- Are there any differences in the level of job satisfaction rating of the instructors based on gender, years of experience, nationality?
- Are there are any differences in the job autonomy rating of the instructors based on gender, years of experience, nationality?

- Are there any relationship between job satisfaction and job autonomy of the instructors?

\section{Research Design}

The study used the descriptive correlation design. The descriptive part presented the teachers job satisfaction rating with a correlation with their job autonomy.

\section{Respondents and Sampling Procedures}

The participants of the study were 70 English instructors, the number of male respondents was 31 and the female respondents were 39. The number of Omanis in the sample was 31 and there were 39 non Omani instructors. Their qualification distributed as 29 with Bachelor, 29 with Master and 4 with Ph.D. The respondents' job experience ranged from 1-33 years. The sample was selected from the language centers in 6 private colleges in Muscat. The respondents were with variety of backgrounds. Table 1 provides the demographic characteristic of the participants in the research.

\begin{tabular}{|l|l|}
\hline Demographic characteristics & Number $\mathrm{n}=70$ \\
\hline Gender & \\
\hline Male & 31 \\
\hline Female & 39 \\
\hline Nationality & \\
\hline Omani & 31 \\
\hline Non Omani & 39 \\
\hline Table1: Demographic characteristics of the participants in the research. \\
\hline
\end{tabular}

\section{Data Collection Instruments}

The study made use of questionnaires. There were three parts of the questionnaire consisting of the demographical part, job satisfaction scale and teacher's autonomy scale. The demographic and personal characteristics part refers to personal background factors related to the respondents such as gender, nationality, years of experience, qualification and social status.

The second part of the instrument is on the job satisfaction questionnaire which was investigated through a 24 item scale. This JSS questionnaire [24] has nine facets namely, pay, promotion, supervision, fringe benefits, contingent rewards (performance based rewards), operating Procedures (required rules and procedures), coworkers, nature of Work, and communication. The original version of this scale is 36 items; however, for the sake of making it shorter, I deleted three subscales with the less coefficient reliability which are Fringe Benefits, Operating Procedures and Coworkers.

The second questionnaire aimed at measuring the job autonomy. This questionnaire was developed using two scales; the first one is the autonomy scale by Deci \& Ryan [21] with 7 items modified to reflect teachers' autonomy. The second scale is MAQ scale [16] consists of 10 items. It measures "the worker's opportunity of freedom, inherent in the job, to determine a variety of task elements, such as method of working, amount of work, and work goals". P.29

In both questionnaires, participants were asked to indicate the degree of agreement with a given statement given on a 6-point scale ranging from "strongly disagree" to "strongly agree". 


\section{Data Analysis}

The data obtained from the questionnaires was computer coded and processed using the Statistical Package for the Social Sciences (SPSS) version 19 and several sets of statistical analyses were performed. Firstly, frequencies of the job satisfaction and job autonomy were obtained and the reliability of both scales was investigated. Secondly, descriptive statistics, that is, the one-sample test, the mean and the standard deviation of the respondents' responses to all the statements in both questionnaires were computed. Thirdly, two independent sample t-tests were conducted to identify the differences between the respondents' background information: a) gender and nationality in the level of their job satisfaction and job autonomy. In order to determine if there is significant relationship between the teachers' job satisfaction and their autonomy, and the two variables with the respondent's experience; bivariate correlation (Pearson-r) was performed.

\section{Results}

First, Cronbach's Alpha coefficients were used to estimate the reliability of each scale. It was .88 for the teachers' job satisfaction scale which indicates fairly a high reliability. Whereas, it was .82 for the teacher's autonomy scale; this value is threshold to accept. Internal consistency reliability also was determined on the teachers' job satisfaction subscales pay, promotion, supervision, contingent rewards, nature of Work, and communication $(\mathrm{r}=.50, .50, .77, .64$, $.68, .73$ ). Table 2 provides the reliability of the measures.

\begin{tabular}{|l|l|l|}
\hline Construct & Number of items & Cronbach's Alpha \\
\hline Pay & 4 & .50 \\
\hline Promotion & 4 & .50 \\
\hline Supervisor & 4 & .77 \\
\hline Reward & 4 & .64 \\
\hline Nature of work & 4 & .68 \\
\hline Communication & 4 & .73 \\
\hline JS whole scale & 24 & .88 \\
\hline JA whole scale & 17 & .82 \\
\hline
\end{tabular}

The next set of statistical analysis was conducted to determine the level of job satisfaction and job autonomy that teachers have. It was the one- sample test. Since six- point Likert item was used to investigate the respondents' means in both scales, the theoretical mean value was 3.5. By comparing the means at $\alpha=.05$, it was apparent that the mean of teachers' job satisfaction was 3.84 which indicates that the teachers display job satisfaction at a high level. The results also demonstrate that the most important subscales of job satisfaction that the teachers' scores high level of satisfaction at was nature of work (4.71). Among the several subscales of the teachers' job satisfaction, the respondents got the lowest mean in pay (3.17).Regarding the job autonomy scale, as indicated by the mean (3.68), the teachers reported medium level of job autonomy. Data shows that among the 17 items of the job autonomy, item 1 got the highest mean; this referred to "I feel like I am free to decide for myself how to teach". While the item 16 which is "I can determine my own working-hours "got the lowest mean. Table 3 points to the analysis of one sample t- tests.

In order to determine whether any differences exist based on the teachers' demographic characteristics (gender, nationality) in their job satisfaction and their job autonomy, two independent sample t-tests were conducted. The results revealed that no significant differences were found with job satisfaction variables and gender. The results further indicate no significant differences between teachers' job satisfaction and nationality except in supervisor. The results indicate that the ' $t$ ' value (11.74) is significant at 0.001 level of significance, so nonOmani teachers have higher mean score (4.69) with regard to the supervisor than female teachers (4.00). With regard to job autonomy, no significant differences were observed for the job autonomy and the two variables gender, nationality. Table 4 shows the mean comparison of gender and nationality on teachers' job satisfaction and their autonomy and it provides analysis for independent-sample t- tests.

\begin{tabular}{|l|l|l|l|l|}
\hline Construct & $\mathrm{M}$ & $\mathrm{SD}$ & $\mathrm{t}$ & Effect size \\
\hline Pay & 3.1750 & .96623 & -2.814 & \\
\hline Promotion & 3.3429 & .95380 & -1.378 & \\
\hline Supervisor & 4.3857 & 1.17853 & $6.288^{* * *}$ & 0.60 \\
\hline Reward & 3.4321 & 1.06825 & -.531 & \\
\hline Nature of work & 4.7107 & .92532 & $10.947^{* *}$ & 0.79 \\
\hline Communication & 4.0214 & 1.16621 & $3.741^{* * *}$ & 0.41 \\
\hline JS whole scale & 3.8446 & .76986 & $3.745^{* * *}$ & 0.41 \\
\hline JA whole scale & 3.6824 & .77635 & 1.965 & \\
\hline $\begin{array}{l}\text { Table 3: Means, Standard Deviations, and the One-Sample t-test on the } \\
\text { Model's Variables (N }=70) . \\
* * * p .005\end{array}$ \\
\hline
\end{tabular}

The results also show that the correlation value (.57) is significant at .000 level of significance, soit is concluded that there is a significant relationship between teachers' job satisfaction and their job autonomy. On the other hand, the results show no significant relationship between teacher's experience and their job satisfaction $(r=.22, \mathrm{P}<0.01)$. It also show no significant relationship between the respondents' year of experience and their job autonomy $(\mathrm{r}=.05, \mathrm{P}<0.01)$. Tables $5,6,7$ show the correlations of the variables.

\section{Discussion}

The basic objective of the present study was to explore the relationship between job satisfaction and the job autonomy. The findings of this study support that the teachers' job satisfaction and teachers' job autonomy are related. Pearson correlation showed that teachers' job satisfaction with different domains is significantly related to teachers' job autonomy. These findings lend support for the findings by Saragih [13] who reported that job autonomy enhances employees' feelings of satisfaction. Taylor et.al, [2] observed positive association between the job autonomy and the job satisfaction as well. Skinner [14] also found that teacher's with high job autonomy had greater job satisfaction. Pearson and Moomaw [15] also examined the relation between teachers' job autonomy and their job satisfaction and they found that since teachers are autonomous in choosing their skills, methods, preferences, they display high level of satisfaction.

Data from both questionnaires suggest that in general the teachers in the sample were satisfied with their occupations. Although a number of domains have been found to play a key role in determining teachers' job satisfaction, nature of work was the most critical one since the highest scores of satisfaction were related to it. The atmosphere of work and its nature provide greater support for the teachers [25]. Studies sustained that finding were done by [1, 3,9, 26, 26 . They all agree at the crucial role nature of work play in enhancing job satisfaction. 


\begin{tabular}{|c|c|c|c|c|c|c|c|c|c|c|}
\hline Variables & & & & Sex & & & & Sig & & \\
\hline \multirow{7}{*}{ Job Satisfaction } & \multicolumn{3}{|l|}{ Male } & & \multicolumn{3}{|c|}{ Female } & \multirow[b]{3}{*}{.36} & $\mathrm{t}$ & df \\
\hline & M & SD & $\mathrm{N}$ & & M & SD & $\mathrm{N}$ & & \multirow[t]{2}{*}{.86} & \multirow[t]{2}{*}{68} \\
\hline & 3.93 & .87 & 31 & & 3.77 & .68 & 39 & & & \\
\hline & & & & Nationality & & & & Sig & & \\
\hline & \multicolumn{3}{|c|}{ Omani } & & \multicolumn{3}{|c|}{ Non Omani } & \multirow{3}{*}{.31} & $\mathrm{t}$ & $\mathrm{df}$ \\
\hline & $\mathrm{M}$ & SD & $\mathrm{N}$ & & $\mathrm{M}$ & $\mathrm{SD}$ & $\mathrm{N}$ & & \multirow[t]{2}{*}{$2.01-$} & \multirow[t]{2}{*}{68} \\
\hline & 3.58 & .54 & 31 & & 4.04 & .86 & 39 & & & \\
\hline \multirow[t]{8}{*}{ Job Autonomy } & & & & Sex & & & & Sig & & \\
\hline & \multicolumn{3}{|l|}{ Male } & & \multicolumn{3}{|c|}{ Female } & \multirow[b]{3}{*}{.36} & $\mathrm{t}$ & $\mathrm{df}$ \\
\hline & M & SD & $\mathrm{N}$ & & M & SD & $\mathrm{N}$ & & \multirow[t]{2}{*}{.86} & \multirow[t]{2}{*}{68} \\
\hline & 3.75 & .72 & 31 & & 3.62 & .81 & 39 & & & \\
\hline & & & & Nationality & & & & Sig & & \\
\hline & \multicolumn{3}{|c|}{ Omani } & & \multicolumn{3}{|c|}{ Non Omani } & \multirow{3}{*}{.06676} & $\mathrm{t}$ & $\mathrm{df}$ \\
\hline & M & SD & $\mathrm{N}$ & & M & $\mathrm{SD}$ & $\mathrm{N}$ & & \multirow[t]{2}{*}{$1.42-$} & \multirow[t]{2}{*}{68} \\
\hline & 3.53 & .67 & 31 & & 3.79 & .83 & 39 & & & \\
\hline
\end{tabular}

${ }^{* * *} \mathrm{p}<.005$

\begin{tabular}{|l|l|l|l|l|l|}
\hline Variables & Mean & SD & N & P. correlation & Sig \\
\hline $\begin{array}{l}\text { Job } \\
\text { satisfaction }\end{array}$ & 3.84 & .76 & 70 & $.57^{\star * *}$ & .000 \\
\hline $\begin{array}{l}\text { Job } \\
\text { autonomy }\end{array}$ & 3.68 & .77 & 70 & & \\
\hline
\end{tabular}

Table 5: Correlation between teachers' job satisfaction and their job autonomy.

${ }^{* * *} \mathrm{p}<.005$.

\begin{tabular}{|c|c|c|c|c|c|c|}
\hline \multicolumn{2}{|l|}{ Variables } & Mean & SD & $\mathrm{N}$ & P. correlation & Sig \\
\hline \multicolumn{2}{|c|}{ Job satisfaction } & 3.84 & .76 & 70 & .22 & .06 \\
\hline \multicolumn{2}{|l|}{$\begin{array}{l}\text { Teachers' } \\
\text { experience }\end{array}$} & 10.74 & 8.91 & 70 & & \\
\hline \multicolumn{7}{|c|}{$\begin{array}{l}\text { Table 6: Correlation between teachers' job satisfaction and their } \\
\text { experience. } \\
* * * \mathrm{p}<.005\end{array}$} \\
\hline Variables & $\mathrm{Me}$ & & SD & $\mathrm{N}$ & P. correlation & Sig \\
\hline $\begin{array}{l}\text { Job } \\
\text { autonomy }\end{array}$ & 3.6 & & 77 & 70 & .05 & .66 \\
\hline $\begin{array}{l}\text { Teachers' } \\
\text { experience }\end{array}$ & 10. & & 8.91 & 70 & & \\
\hline
\end{tabular}

Table 7: Correlation between teachers' job autonomy and their experience.

${ }^{* * *} \mathrm{p}<.005$

Although satisfaction seemed to be more associated with personal factors, the payments factors cannot be ruled out. The results exposed that pay is the less satisfied domain for the instructors. Providing a higher salary would be the most effective step in satisfying the teachers. These results also support the findings of Ozen [5] and Ghenghesh [7] who found that pay and salary is the less satisfied aspect among the teachers. One explanation for this is "teachers need sufficient payment not just for their living expenses as clothing, food etc, but also for their personal and academic improvement" [8].
With regards to the nationality, the results clarify no significant relationship between nationality and job satisfaction except in supervisor subscale. Further findings from this study indicate that nonOmani instructors are more satisfied than Omani ones in the supervisor subscale. These findings support the findings of Moore [6] who found that even if the supervisor's relationship is ideal with the teachers, there is still a large discrepancy in the level of satisfaction among instructors with different backgrounds working in the same place. We can contribute this finding to the life circumstances of the non Omani instructors since they need to work to meet their life' needs; regardless of what they face. They try to make good relationships with all people at work especially the supervisors. Therefore, they are more satisfied with what they face at work.

The results also show no significant relationship between nationality and job autonomy. This is could be explained that all groups encounter the same work circumstances, same duties and same nature of work in which they finally display a similar level of autonomy.

Previous researchers related teachers' teaching experiences and suggested tow points of view. Some of them suggested that less years of experience lead to more satisfaction [1]. While others [5, 27-30] reported that more years of experience result in less satisfaction. Although in many professions, increased length of service may lead to boredom and dissatisfaction with an occupation [25,31-34]; this is not supported by this study. This research didn't reveal a relationship between teacher's job satisfaction, their autonomy and years of experience. This result might be due to the low reliability coefficients of the JS scale, the small sample, the randomness in the responses.

\section{Educational Implications}

The implications of this study are significant because of the vital variables examined. They can be evidently implied into theoretical and practical educational scopes. First, the results highlight the consequence of teachers' job autonomy in enhancing their job satisfaction. Therefore, efforts should be directed to achieve teachers' job satisfaction through adopting autonomy principles and providing 
Citation: Al-Siyabi NS (2016) Assistive Technology for Promoting Adaptive Behaviors of Children with Cerebral Palsy. Int J Psychol Behav Anal 2: 111. doi: http://dx.doi.org/10.15344/2455-3867/2016/111

Page 5 of 6

opportunities for the instructors to self- pace themselves. Involving in decision making, modifying the work environment, generating new ways of communications are some central strategies to attain teachers' job autonomy.

As far as improving the job satisfaction for teachers, principals should identify Omani teacher's need through supervisors' recognition. Thus, through this identification, the study provides enormous extent for the improvement of job satisfaction through clarifying the role of the supervisors, provide a productive work environment. With regard to the specific findings, payments and promotions need to be highly examined and reinforced in better insights.

\section{Limitations and suggestions for future studies}

The current study points out worth noting limitations. First, the investigations of this study were limited to instructors working in the language centers in private colleges in Muscat. Similar studies can be conducted in governmental educational institutions in relation to different variables. Second, the number of the sample was small due to the difficulties in reaching enormous number of instructors; this caused challenges in configuring differences and relations between the variables. In the light of that limitation, future studies should extend findings using a large sample that can be more representative. Third, the data of this study was collected through questionnaires, future studies can be carried out using interviews or teachers' daily dairies. Finally, adopting sophisticated analysis and adding more variables might help in examining the relation between teachers' job satisfaction and their job autonomy.

\section{Conclusion}

It is evident that job satisfaction and job autonomy are crucial issues for the thriving education. Therefore, this study aims at exploring the relationship between teacher's job satisfaction and their job autonomy through analyzing facets related to job satisfaction.

Based on the findings of this study, the teachers display high levels of job satisfaction and job autonomy. It was seen that job satisfaction was high within the nature of work subscale; this will definitely result in productive teachers. In contrast, payment was the less satisfied aspect for the respondents; this finding indeed was consistent with other published research findings.

Importantly, evidence provided by this study indicates that there is a positive relationship between job satisfaction and job autonomy. The job autonomy among Omani and non Omani teachers display slight discrepancies in which non Omani teachers show higher satisfaction than Omani ones regarding supervisor. Further, the results obtained from this study indicate no significant differences in teachers' job satisfaction and their job autonomy according to the respondent's gender, or years of experiences.

Despite the fact that the study was restricted by fairly small sample, it presents obvious representation of the concern of teachers' job satisfaction and job autonomy.

\section{Competing Interests}

It is evident that job satisfaction and job autonomy are crucial issues for the thriving education. Therefore, this study aims at exploring the

\section{References}

1. Gupta M, Gehlwat M (2013) Job satisfaction and work motivation of secondary school teachers in relation to some demographic variables: A comparative study. Edu Confab 2: 10-19.

2. Taylor J, Bradley S, Nguyen AN (2003) Job autonomy and job satisfaction: new evidence. (Economics Working Paper Series). Lancaster University: The Department of Economics.

3. Ali S, Ganai M (2013) Job satisfaction of higher secondary school teachers in relation to their seniority and stream of education. Merit Res $\mathrm{J} 1: 1-5$.

4. Perveen U, Ghughati F (2013) A study of teachers' workload and job satisfaction in public and private schools at secondary level in Lahore city Pakistan. Asian J Social Sci Human 2: 1-13.

5. Ozen $Y$ (2013) Relationship of various social variables with primary teacher's job satisfaction. The Online J Counsel Edu 2: 59-82.

6. Moore C (2012) The role of school environment in teacher dissatisfaction among U.S. public school. Sage 1-17.

7. Ghenghesh $P(2013)$ Job satisfaction and motivation- what make teachers tick? British J Edu Soc Behav Sci 34: 456-466.

8. Peter J (2013) Workload, stress and job satisfaction among Waldorf teachers: An explorative study. Res Stein Edu 3: 111-117.

9. Agyekum N, Suapim R, Peprah S (2013) Determinants of job satisfaction among Ghanaian teachers. J Edu Prac 4: 43-50.

10. Gagné M, Deci E (2005) Self-determination theory and work motivation. J Organiz behave 26: 331-362

11. Hackman J, Oldham G (1980) Work redesign. Reading MA: AddisonWesley.

12. Langfred C, Moye N (2004) Effects of task autonomy on performance: An extended model considering motivational, informational, and structural mechanisms. J App Psy 89: 934-960.

13. Saragih S (2011) The effects of job autonomy on work outcomes: Selfefficacy as an intervening variable. Int Res J Business Stud 4: 203-215.

14. Skinner R (2008) Autonomy, working conditions, and teacher satisfaction: Does the public charter school bargain make a difference? George Washington University: UMI ProQuest Digital Dissertations.

15. Pearson L, Moomaw W (2005) The Relationship between teacher autonomy and stress, work satisfaction empowerment, and professionalism. Edu Res Quart 29: 38-54.

16. De Jonge J (1995) Job Autonomy, Well-being, and Health: A study among Dutch health care workers, $\mathrm{PhD}$ thesis, Datawyse, Maastricht.

17. Dobbin F, Boychuk T (1999) National employment systems and job autonomy: Why job autonomy is high in the Nordic countries and low in the United States, Canada, and Australia. Organiz Stud 20: 257-291.

18. Broeck A, Vansteenkiste M, Witte H, Soenens B, Lens W (2010) Capturing autonomy, competence, and relatedness at work: Construction and initial validation of the work related basic need satisfaction scale. J Occup Organ Psychol 83: 981-1002.

19. Dennie T (2012) Perception of autonomy and its effect on intrinsic motivation, immersion, and performance. ProQuest 1-66.

20. Bekker MH, van Assen MA (2006) A short form of the Autonomy Scale: properties of the Autonomy-Connectedness Scale (ACS-30) J Pers Assess 86: $51-60$

21. Deci E, Vallerand R, Pelletier L, Ryan R (1991) Motivation and education The self-determination perspective. The Edu Psychol 26: 325-346.

22. Lange T (2012) Job satisfaction and self-employment: Autonomy or personality? Small Business Econom 38: 165-177.

23. Samman E (2007) Psychological and subjective well-being: A proposal for internationally comparable indicators. Oxford Develop Stud 35: 459-486.

24. Spector $P$ (1985) Measurement of human service staff satisfaction: Development of the job satisfaction survey. Ame J Commun Psychol 13: 693-713. 
Citation: Al-Siyabi NS (2016) Assistive Technology for Promoting Adaptive Behaviors of Children with Cerebral Palsy. Int J Psychol Behav Anal 2: 111. doi: http://dx.doi.org/10.15344/2455-3867/2016/111

Page 6 of 6

25. Bishay A (1996) Teacher motivation and job satisfaction: A Study employing the experience sampling method. Journal of Undergraduate Sciences, 3 : 147-154.

26. Nisamudheen T (2013) Job satisfaction among college teachers: A study on government colleges in Kerala. Trans Asian J Market Manag Res 2 33-41.

27. Hanfstingl B, Andreitz I, Müller F, Thomas A (2011) Are self-regulation and self-control mediators between psychological basic needs and intrinsic teacher motivation? J Edu Res Online 2: 55-71.

28. Meng L, Ma Q (2015) Live as we choose: The role of autonomy support in facilitating intrinsic motivation. Int J Psychophysiol 98: 441-447.

29. Roth G, Assor A, Kanat-Maymon Y, Kaplan P (2006) Autonomous motivation for teaching: How self-determined, teaching may lead to selfdetermined learning. J Educ Psychol 99: 761-774.

30. Ryan RM, Deci EL (2000) Intrinsic and Extrinsic Motivations: Classic Definitions and New Directions. Contemp Educ Psychol 25: 54-67.

31. Ryan R, Deci E (2008) Self-determination theory: A Macro theory of human motivation, development, and health. Canad Psychol Assoc 49: 182-185.

32. Ryan R, Deci E (2013) Self determination theory.

33. Usma J (2009) Teacher autonomy: A critical review of the research and concept beyond applied linguistics. Íkala 12: 245-275

34. Usop A, Askandar K, Kadtog M, Usop D (2013) Work performance and job satisfaction among teachers. Int J Human Soc Sci 3: 245-252. 